\title{
Bullet Babies: The Repeating Nature of the Medical Hoax
}

\author{
Harry Herr* \\ From the Department of Urology, Weill Cornell Medical College New York, New York. \\ *Correspondence: Sectin of Urology, Memorial SLoane Kettering Cancer Center, 1275 York Avenue, New York, New York; e-mail: hherr@mskcc.org
}

Introduction: Incredible tales of medical hoaxes associated with virgin births have been recounted through history. Some reports exist of wartime gunshot testicular injuries that caused pregnancy in a second bullet victim. This paper sought to identify the sources and circumstances of such tales and how similar legends appear to be perpetuated in medical historical lore.

Sources: Medical journals, contemporary newspaper accounts, and archives of secondary lay-press magazines and periodicals.

Results: The first known episode of a pregnancy conceived via bullet wound occurred in the American Civil War. A woman claimed to become pregnant from being shot by a bullet that had passed through the scrotum of a Civil War soldier. In reality, the tale had been fabricated by a doctor who wanted to tease his colleagues over their boastful surgical triumphs. A second such 'bullet baby' was reported in 1999 during the Bosnian conflict. The two episodes, despite their lack of medical credulity, were perpetuated in the medical press by reputable authorities.

Conclusions: History sometimes offers a storyline that may be so fantastical that even medical authorities may either disregard its impossibility or unknowingly prolong its life.

Keywords: Minie ball, virgin birth

$\mathrm{M}$ edical hoaxes and virgin births as isolated events are believed by some when authorities declare them plausible.(1) Some tales of cause and effect are so implausible, they strain the credulity of even the most gullible. $(2,3)$ An example is the story of a woman who became pregnant from being struck by a bullet that had passed through the testicle of a Civil War soldier. $(4,5)$ Often ridiculed as a 'bullet baby' or 'son of a gun', a bullet-mediated pregnancy in a woman reportedly happened not once, but twice.(6) One of the cases has been repeated and retold in reputable medical journals, mostly lampooned as a hoax, but insisted by some as authenticated fact. $(4,7,8)$. This manuscript sought to investigate the details of these reports, the individuals involved with them, and how these tales could be substantiated by medical authorities.

\section{SOURCES}

The manuscript surveyed archives of medical journals, the lay press periodicals, and contemporary newspapers from 1874 to the present that were related to the events of interest.

\section{RESULTS}

The Case of the Miraculous Bullet. On May 12, 1863, A Confederate Army doctor named LeGrand G. Capers was working in a field hospital in Mississippi, while the Battle of Raymond raged around him.(Figure 1) Three hundred yards behind the rebel lines was a house. On the porch was a mother and her two daughters, watching the action, ready to aid their fallen brethren. As the battle drew near to Dr. Capers, a soldier stumbled forward and fell to the ground. He had been shot in the leg, fracturing his tibia. The bullet "ricocheted off the bone and passed through his scrotum, carrying away his left testicle."(7) At the same time, Dr. Capers heard a piercing scream from the house. He addressed the soldier's wounds, when the mother from the house ran up and urged him to see her daughter. He complied and therein found a badly wounded young lady. A 'Minié' ball had "penetrated the left abdominal parietes, midway between the umbilicus and anterior spinal process of the ilium, and was lost in the abdominal cavity...". Believing the wound was mortal, and threatened by the enemy, Dr. Capers only had time to prescribe an anodyne before he was forced to retreat with his regiment.

https://doi.org/10.53101/IJUH.1.2.1152202 Vol. I (2), 72-75, January 2022 Electronically distributed 


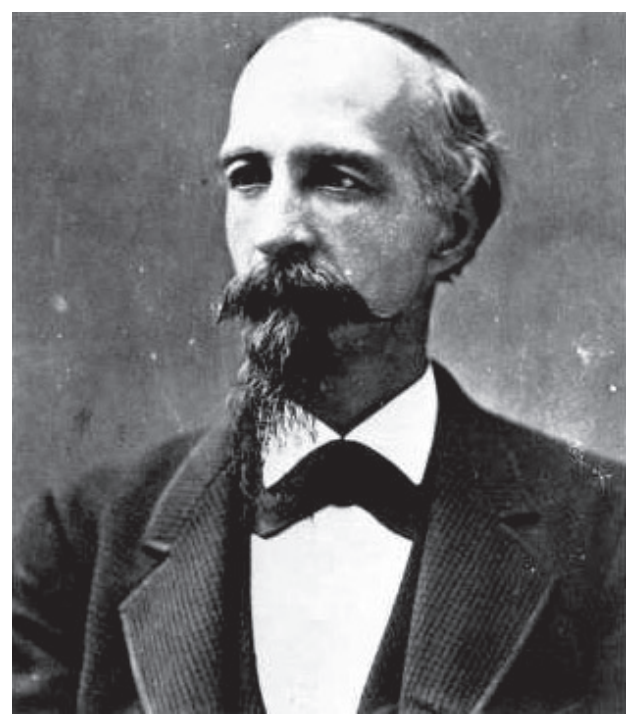

FIGURE 1 LeGrand G. Capers (1834-1877) hoped to be the anonymous author of the Pregancy-via-Minié Ball case were it not for the exceptional detective work of his editor who exposed the 1874 'caper'. Still, Dr. Capers had a long and, by all accounts, illustrious career in surgery and medicine, teaching at the New Orleans School of Medicine. His death, "stricken down in the glorious noon of his manhood", rocked Vicksburg (24).

He stayed behind in Raymond to care for the wounded and regularly visited the young girl. She suffered from peritonitis but remarkably recovered in two months. Six months later, Dr. Capers happened to be back in Raymond. He visited the girl and found she was in advanced stage of pregnancy. She insisted she was "pure and innocent" and had never had sex. Dr. Capers examined her and found the hymen intact. A month later, he delivered a healthy eight-pound baby boy, 278 days after the mother had been shot. Three weeks after the birth, the girl's grandmother asked Dr. Capers to see the child because there was "something wrong about the genitals." He detected a hard body embedded in the infant's scrotum and removed it. It was a Minié ball.

Dr. Capers agonized over this case and after several sleepless nights, he had an epiphany. He knew what must have happened. The Minié ball he removed from the infant was the same one that had wounded the soldier. "The bullet had plunged through the testicle," he conjectured "carrying particles of semen and spermatozoa into the abdomen of the young lady, through her left ovary, and into her uterus, and in this manner impregnated her. There can be no other solution of the phenomenon."(7) He informed the daughter who requested to meet the soldier. She married him and the couple had two more children the conventional way.
In 1874, eleven years later, Dr. Capers published his witnessed account in American Medical Weekly, a Louisville, Kentucky periodical.(7) He submitted it anonymously to disassociate himself from the article and as a joke to poke fun at the numerous, highly embellished, often spurious, Civil War stories then being told in the 1870s. The wily editor, Dr. E.S. Gaillard, was not hoodwinked. He recognized Dr. Capers' handwriting and printed the piece naming him as the author. The editor noted Dr. Capers disclaimed responsibility for the truth of that remarkable case of impregnation by a Minié ball....but "he does not say it is untrue, only that 'accidents may happen in the best regulated families.' " The editor punned "the readers have enjoyed the story much, but not enough 'to cut capers' after reading it."(9) Dr. Capers' intention was more serious in nature and clearly stated in the introduction of his account. "How common it is now-a-days," he wrote, "for men to tell wonderful stories about 'the war', their desperate charges, hair-breadth escapes, numbers who have fallen victims to their feats of personal valor, etc., etc. Then every surgeon has performed any number of wonderful operations before unheard of in the annals of surgery!"(7)

The Story Lives. After it appeared, this Civil War story became something of a legend. Its origins and details became obscured, but the basic outline of the tale was 

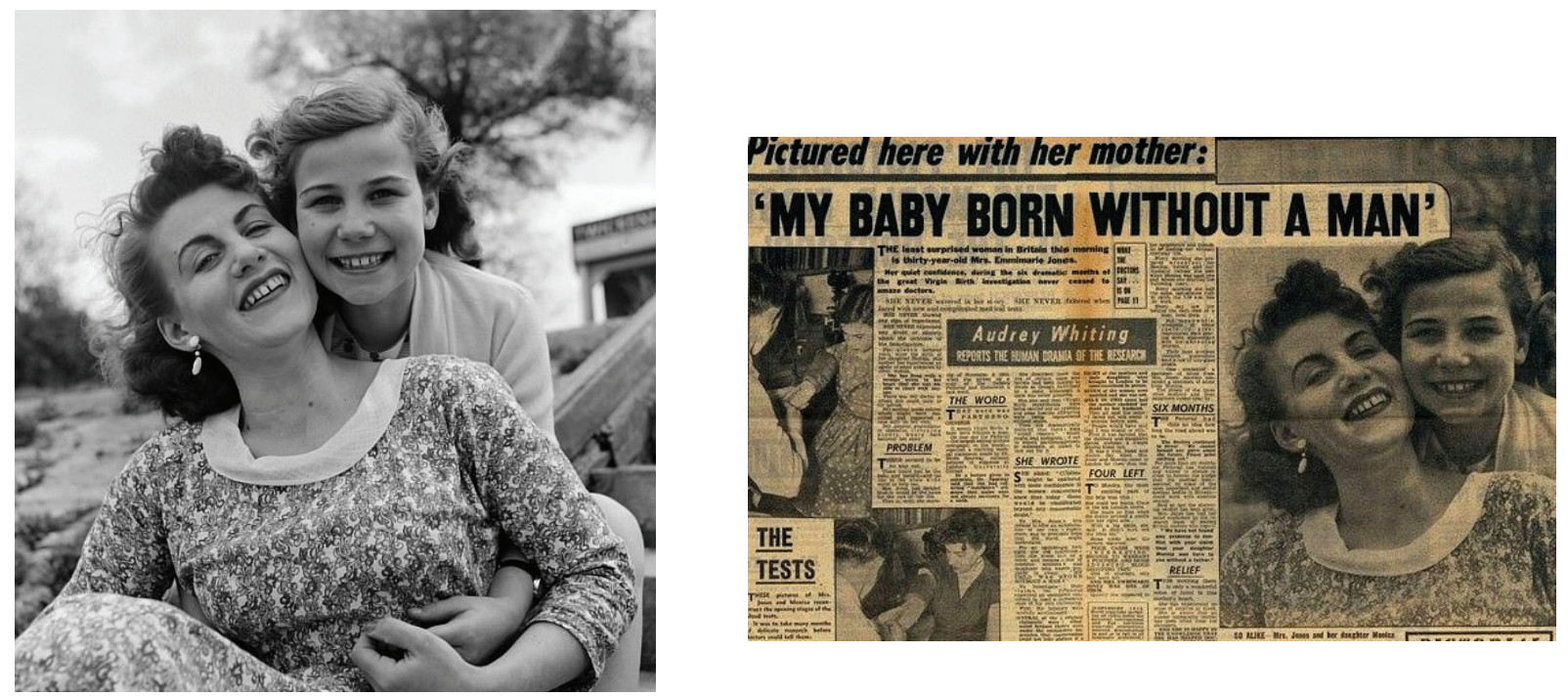

FIGURE 2. The World Wide Web of Tales. (Left) Emmimarie Jones and her daughter, Monica, who was purportedly born via parthenogenesis, in post war Germany (Mirrorpix, London). (Right) This 1955 newspaper article by Audrey Whiting (Sunday Pictorial, London) on the Jones' case has been posted for years on the internet to depict the unrelated Bosnian 'Bullet Baby' case described in this manuscript although the latter purportedly occurred nearly 40 years later, $(6,19)$

frequently repeated. Dr. Capers' case of a virgin birth was portrayed usually as a humorous hoax but often as fact. As early as 1875, The Lancet reported the event as a veracious chronicle and it was further embellished in Anomalies and Curiosities of Medicine, published in 1896. $(10,11)$ Even up to 1959, a respected obstetrician specialist in New York authenticated the tale as factual, asserting the incident could have happened, writing "no other solution to this birth was apparent."(4) In 1981, James Breeden sought to debunk the myth and tell the truth, declaring it a hoax (12). Dr. Capers was said to have "carefully recorded" the remarkable case "for the annals of medicine." "Doubtless", Breeden concluded, "many will pronounce the acts to be presently related as unusual or impossible; to such I need only to say, if not, why not?" Breeden asserts Dr. Capers was indeed poking fun at the braggadocio of his wartime colleagues. But the story did not end there. Dr. Capers' tale was reproduced in part again in The Lancet in 1989, by The Atlantic magazine in 2015, The Old Farmer's Almanac in 2018, and American History in 2019. (13-16) Even the television program "Mythbusters" devoted a whole episode attempting to see if a bullet-mediated pregnancy was possible.(17) They found that although a bullet could travel through a body and then another 300 yards, it could not penetrate a womb, nor could sperm survive the heat or friction of a rifled bullet.

Bosnian Bullets and Babies. An American woman in Bosnia gave birth to a baby girl, conceived, according to doctors, by a bullet that "pierced her stomach" after it hit a man in the testicles.(6) She claimed to be a virgin and thus represented the second reported case of a bullet-mediated pregnancy reported in the world.(Figure 2) Leslie Corbide was a nurse with the United Nations deployed in Bosnia in February, 1988 when she was wounded in a shootout between military police and a group of ne'er-do-wells. A bullet hit her in the lower abdomen. Six weeks later, complaining of absent menses and morning sickness, she insisted on a pregnancy test. A gynecologist who examined her discovered she was a virgin and was astounded when the test came back positive. In November, 1988, she gave birth to a baby girl weighing five pounds. The doctors were perplexed. Review of medical records showed that one of the police officers close to Carbide at the time was also shot. The doctors assumed the bullet hit the man's testicles, taking a small quantity of sperm to reach the uterus and inseminated Leslie. An analysis of the child and the father's genes demonstrated that the physicians' assumption was correct. No medical reports verifying the so-called 'virgin birth' are recorded. The story was rated "the most stupid piece of news of 2003."(19)

\section{DISCUSSION}

This manuscript investigated the details of two pregnancies in history potentially conceived through the high velocity traumatic transportation of spermatozoa from a father into the womb of the mother via bullet. 
We found that there are two such tales of 'bullet babies' and that their permanence in folklore was perpetuated, in part, by their repetition and acceptance in bona fide medical professional and lay literature. $(1,8,14) \mathrm{Dr}$. Caper's 'caper' has maintained its popularity for over 150 years despite a thorough dressing-down by the television program, "Mythbusters", which demonstrated that the inhospitable heat and trauma of bullet's projectory would preclude sperm viability.

There have been other instances where medical 'authorities' have validated and thereby perpetuated such hoaxes, a tendency of the self-serving that may even continue today. Nathaniel St. André (1680-1776), once personal physician to King George I, was duped by a one Mary Toth (1701-1763), who claimed to have given birth to a series of rabbits first reported by her obstetrician Mr. John Howard.(20) Mary's eventual confession cost St. André his career and livelihood, who himself refused to eat rabbits for the last 50 years of his life. (2) Complicity by medical doctors in these tales can even sway jurisprudence. In 1637, four physicians from Grenoble provided sworn avidavits that a young Magdeleine d'Auvermont could have become legitimately pregnant by her long-absent husband merely by dreaming of him. (21) Intentional hoaxes by medical men like Capers are also not unusual. Sir John Hill pseudonomously published articles on 'animalculi' which could float in the air and impregnate the ignorant, as an alternative to a contemporary 'spermist theory' of 'homunculi'.(22) Hoaxes, in this regard, seem to be a vehicle by physicians, like Drs. Hill and Capers, to exact revenge on the medical establishment through satire. (1)

Hoaxers, frauds, quacks, and charlatans are as old as the medical profession itself. Dr. Capers may have written his 'surgical triumph' in response to outlandish claims that had been given legitimacy in the medical literature which had no means of checking sources. His death in 1877 prompted the regular physicians of Vicksburg and Warren county to meet and discuss the legacy of their "friend and confrere."(23) "Stricken down in the glorious noon of his manhood...(he) was ever the same high-toned, honorable gentleman, rigidly adhering to the letter and spirit of the 'Code of Medical Ethics'."(24) Thus, it appears that his only known publication, while a satirical story, was viewed by his admiring colleagues as just that, a 'story'.

\section{CONCLUSION}

Impregnation by bullet may be physically impossible but, like other medical hoaxes, achieved some credibility when reported and authenticated by physicians.

\section{REFERENCES}

1. Boese A: Museum of Hoaxes 2015; 2021: .

2. Bondeson J: Cabinet of medical curiosities. New York: WW Norton \& Co. 1997.

3. Scarlett EP: Some hoaxes in medical history and literature. Arch Int Med 1964; 113: 291.

4. Napolitani F: Two Unusual Cases of Gunshot Wounds of the Uterus. New York State J Med 1959; 59: 491.

5. Schickel R: The Case Of The Miraculous Bullet. Amer Heritage 1971; 23: 99.

6. Boom: She was a virgin and she conceived a baby with a bullet! Second case in the world!. Boomviral net 2014; 2021: .

7. Capers L: Notes from the Diary of a Field and Hospital Surgeon, C.S.A. Amer Med Weekly 1874; 1: 233.

8. Editor: Original Communications. Atl Med Surg Journal 1874; 12: 562.

9. Editor: Miscellaneous. Amer Med Weekly 1874; November $21^{\text {st: }}, 263$.

10. Anonymous: A veracious chronicle. Lancet 1875; January $2^{\text {nd: }} 35$.

11. Gould GM, Pyle WL: Anomalies and Curiosities of Medicine. Philadelphia: W.B. Saunders, 1896.

12. Breeden JO: "The case of the miraculous bullet" revisited. Mil Aff 1981; 45: 23.

13. Gordon AC, Spicer RD: Impregnated via a bullet. Lancet 1989; April 1st: 737.

14. Lamere $B$ : The first case of artificial insemination by a bullet. Old Farm Alman 2021; November $12^{\text {th }}$.

15. Eveleth R: Impregnated by a speeding bullet. The Atlantic 2015; November $18^{\text {th }}$.

16. Powell JM: The Minié ball pregnancy. Amer History 2019; February $16^{\text {th }}$.

17. "Son of a gun", Episode 6. Mythbusters 2005; Television: March $30^{\text {th }}$.

18. A virgin gives birth. The Graduate 2004; 1 : 12.

19. Racovitan D: The stupidest news of January. Cafeneaua January, 2004. See www.cafeneaua.com/nodes/ show/923/cea-mai-stupida-stire-a-lunii-ianuarie/1

20. Saint-André N, Howard J: A short narrative of an extraordinary delivery of rabbets (sic). London: John Clarke 1727.

21. Parlement de Dauphiné: Arrest notable de la cour de parlement de Grenoble, Octavo $\left(8^{\circ}\right) 1637 ; 8$.

22. Hill J: Lucina sine concubiti: A treaty humbly addressed to the Royal Society 1885 ; .

23. Whitehead PF, Shannon H: Death of Dr. L.G. Capers. New Orleans Med Surg Journal 1878; 5: 736.

24. Henry ET, Shannon H, Barnett JR et al: Death of Dr. L.G. Capers. American Med Bi-Weekly 1878; 8: 13. 